\title{
Politik Identitas Islam dan Urgensi Pendidikan Multikultural
}

\author{
Nafik Muthohirin \\ Universitas Muhammadiyah Malang, Indonesia \\ nafikmuthohirin@umm.ac.id
}

\begin{abstract}
This article highlights the politics of Islamic identity that appears through persecution and religious-based violent extremism. During the past two decades, the hustle and bustle of public space seem to be filled with various religious symbols, which visibly deep respect for the reality of diversity while reducing the critical role of Pancasila as the ideology of the Indonesian state. If such behaviour is carried out in a corridor that upholds the values of Pancasila, then that attitude is not a problem. However, because the imposition of Islamic identity is accompanied by expressions of hatred and other judgmental attitudes, this needs to be anticipated. In fact, in several cases, this other judgmental attitude often leads to the mobilization of the masses to execute those who are considered different from the majority. Such a social situation can tear the religious plurality that has fostered this nation for a long time. Therefore, this article seeks to examine several things, namely: (1) tracking various acts of intolerance based on the politics of religious identity; (2) agencies that play an essential role in the occurrence of acts of persecution; (3) rethinking the urgency of multicultural education.
\end{abstract}

Keywords. Identity Politics; Islam; Multiculturalism; Execution.

\begin{abstract}
Abstrak. Artikel ini menyoroti politik identitas Islam yang tampil melalui aksi persekusi dan tindak ekstrimisme kekerasan berbasiskan agama. Selama dua dekade belakangan ini, hiruk pikuk ruang publik tampak dipenuhi berbagai simbol agama, yang secara kasat mata mengaburkan penghargaan terhadap realitas keberagaman sekaligus mereduksi peran penting Pancasila sebagai ideologi negara Indonesia. Bila perilaku yang demikian dilakukan dalam koridor menjunjung tinggi nilai-nilai Pancasila, maka sikap tersebut tidak menjadi masalah. Namun, karena pemaksaan identitas keislaman itu dibarengi ujaran kebencian dan sikap menghakimi yang lain, hal ini perlu diantisipasi. Bahkan, dalam sejumlah kasus, sikap menghakimi yang lain ini tak jarang berujung pada pengerahan massa untuk mempersekusi pihak yang dianggap berbeda dari mayoritas. Situasi sosial yang seperti itu dapat mencabik pluralitas keagamaan yang dipupuk bangsa ini sejak lama. Sebab itu, artikel ini berusaha untuk mengkaji beberapa hal, yaitu: (1) melacak berbagai tindak intoleransi yang didasarkan pada politik identitas keagamaan; (2) agensi yang berperan penting bagi terjadinya tindak persekusi; (3) memikirkan kembali urgensi Pendidikan multikultral.
\end{abstract}

Kata kunci. Politik Identitas; Islam; Multikulturalisme; Tindak Persekusi.

Copyright (C) J-PAI: Jurnal Pendidikan Agama Islam. All Right Reserved.

This is an open-access article under the CC BY-SA license

(https://creativecommons.org/licenses/by-sa/4.0/).

Correspondence Address: jpai@uin-malang.ac.id

\section{A. PENDAHULUAN}

Dalam beberapa tahun terakhir, politik identitas menjadi wacana menarik yang didiskusikan dalam berbagai disiplin keilmuan. Studi ini senantiasa dipakai oleh para sarjana karena berkelindan dengan sektor teritori, daerah, budaya, sejarah, agama, dan konstruksi sosial, serta distingsi antara individu dengan individu yang lain. Secara umum, identitas itu dibentuk sesuai dengan konteksnya (Karami: 2004). Setelah aksi terorisme yang menghancurkan Phentagon dan World Trade Center (WTC) di Amerika Serikat, studi ini mengalami kekhasan dengan lebih mengkhususkan pada isu-isu keagamaan, khususnya Islam dalam hal ini. Identitas Islam pada kenyataannya mengindikasikan rasa kepemilikan dan komitmen seseorang atau kelompok dalam beragama, baik secara privat maupun dalam kehidupan sosial-keagamaan secara kuat. Konsep paling dasar dan penting dari pencapaian politik identitas adalah menjawab 
sejumlah pertanyaan dasar tentang pentingnya kehidupan beragama di kancah sosial, serta menguatkan keimanan dan memberikan makna bagi dunia.

Politik identitas Islam merupakan fenomena lama yang terjadi pada bangsa ini. Keberadaannya berusia tua seiring dengan perjalanan masuknya Islam di Nusantara. Pada abad ke-16, sejumlah kerajaan Islam di Nusantara menjadi simbol kekuatan politik Islam untuk bersatu mengusir penjajah. Kerajaan Islam Jepara dengan kepemimpinan Ratu Kalinyamat memiliki peran penting dalam aksi solidaritas Islam ini. Di era awal kolonialisme itu, Kalinyamat mengirimkan sebanyak 400 armada kapal ke Malaka untuk membantu Kerajaan Malaka berperang melawan Portugis. Selain itu, Jepara juga memimpin ekspedisi perang membantu Kerajaan Aceh dan Ternate-Tidore untuk melawan penjajah yang sama. Puncak dari politik identitas Islam yang ditampilkan melalui kerajaan Islam adalah saat terjadinya Perang Diponegro (1825-1830). Segala atribut keagamaan dimunculkan untuk memobilisasi kekuatan umat Islam melawan Belanda. Para tentara mengikuti pergerakan Pangeran Diponegoro memakai sorban dan jubah ala masyarakat Arab, serta memberikan gelar islami kepada para panglima perang. Identitas Islam juga ditampakkan dengan menyebut perang ini sebagai Perang Sabil/Jihad melawan tentara kafir.

Persentuhan identitas Islam dengan bangsa ini, utamanya masyarakat Jawa juga terjadi melalui kebudayaan. Pada abad ke-17, raja terbesar di Jawa pasca keruntuhan Majapahit, yaitu Sultan Agung yang merupakan penguasa Dinasti Mataram (1613-1646) sukses mendamaikan dan mempertemukan praktik-praktik islami dengan tradisi keraton. Pada era ini, identitas islamik ditampilkan dengan pendekatan mistik, seperti memperkenalkan berbagai literatur islami dengan kekuatan magis yang berasal dari khazanah literer istana (Ricklefs: 2013). Persentuhan keduanya ini berlangsung lama, dan faktor ini menjadi salah satu kesuksesan besar dari proses islamisasi di tanah Jawa pasca jatuhnya Majapahit sebagai kerajaan Hindu-Budha. Politik identitas Islam berlanjut ketika benih-benih pergerakan kemerdekaan Indonesia disuarakan. Ricklefs mencatat dari tahun 1930-an hingga abad kontemporer sekarang, sejarah bangsa Indonesia tidak pernah lepas dari persentuhan identitas umat Islam.

Demokrasi yang dipilih para founding fathers/mothers sebagai sistem pemerintahan negeri ini, juga selaras dengan prinsip-prinsip Islam. Hal itu memberikan gambaran bahwa demokrasi yang dipraktikan bangsa Indonesia adalah bagian dari politik identitas Islam, meski penulis yakin banyak pihak yang menentang pernyataan ini. Namun, jika ada sebagian Muslim yang tetap mempersoalkannya, tidak perlu ditakuti karena logika perspektif yang dibangunnya sulit dipertimbangkan. Jadi, konsep negara-bangsa yang berjalan di Indonesia sejak kemerdekaan hingga saat ini -dan selamanya akan berjalan selama negeri ini masih kokoh berdiri- merupakan wujud politik pengakuan yang dipraktikan dan dijiwai umat Islam Indonesia (Maarif: 2009). Alasan kenapa demokrasi yang dipraktikan bangsa Indonesia selama ini memiliki klaim sebagai wujud politik identitas Muslim karena meski konsep ini bermula dari Barat, namun kelompok dari unsur santri seperti Muhammad Nastir, Wahid Hasyim, Jusuf Wibisono, Idham Chalid, Mohammad Roem, Tjokroaminoto, Agus Salim, Sjafruddin Prawiranegara, Prawoto Mangkusasmito, Kasman Singodimedjo, Sukiman Wirjosendjojo, dan lainnya, mereka ini pendukung demokrasi dan pembela konstitusi. Komitmen mereka terhadap cita-cita demokrasi tentu tidak sama, tapi perjuangan atas sistem ini mereka lakukan sesuai dengan konteksnya masing-masing. Karena kelompok santri memiliki andil besar terhadap pembentukan ideologi negara dan sistem pemerintahan ketika awal kemerdekaan, maka secara filosofis dan substantif, Pancasila dan demokrasi yang dipraktikan bangsa ini memiliki nilai ketuhanan dan kemanusiaan yang sangat kuat.

Kenyataan ini jelas berbeda dengan demokrasi yang dipraktikan negara-negara Barat sekarang. Jika praktik demokrasi di Indonesia disuarakan oleh kelompok agama (khususnya Islam), justru di Barat praktik demokrasi ditandai dengan pudarnya agama. Argumentasi ini dengan sangat kokoh diamini Yudi Latif dalam sebuah karyanya yang monumental berjudul Negara Paripurna: Historisitas, Rasionalitas dan Aktulitas Pancasila. Menurutnya, kekuatan 
agama senantiasa hadir dalam relung perjalanan sejarah Indonesia. Histori perkembangan bangsa ini menyiratkan suatu sikap kejiwaan yang berbeda dengan perkembangan nasionalisme di Eropa. Sikap beragama masyarakat Indonesia tidak terjebak pada praktik keagamaan yang privat, tapi juga terlibat dalam urusan publik (Latif: 2017). Pada konteks ini, menjadi terang-benderang, dalam bernegara pun warga Indonesia tidak bisa terlepas dari agama mereka. Keterlibatan agama dalam urusan bernegara dapat diperhatikan, misalnya dengan keberadaan Kementerian Agama, Peraturan Daerah Berbasis Syariah, serta konstitusi Negara yang memuat nilai atau yang berlandaskan doktrin keagamaan.

Rentang sejarah yang panjang menempatkan bangsa ini sulit melepaskan diri dari identitasnya sebagai masyarakat yang beragama. Karena itu, untuk membuat dikotomi antara Islam dengan kewargaan, baik dari sisi kehidupan berbangsa dan bernegara maupun aktivitas sosial sehari-hari, sangatlah tidak mungkin. Ketidakmungkinan ini menjadi salah satu faktor yang menyebabkan kerap munculnya simbol-simbol keislaman di ruang publik, seperti larisnya penjualan buku-buku islami, sinetron islami, tren fashion islami, perbankan syariah dan perumahan islami. Pada tahap ini sesungguhnya bisa dimaklumi, apalagi dalam iklim demokrasi seperti sekarang yang memungkinkan segala ekspresi hadir di ruang publik. Laporan riset Center for Religious and Cross Culture (CRSC) Universitas Islam Negeri Syarif Hidayatullah Jakarta pada 2011 menyikapi maraknya simbol-simbol Islam di ruang publik ini sebagai sinyal positif yang tidak akan mengancam masa depan demokrasi dan pluralisme di Indonesia. Faktor terpenting yang membuat kita optimis dengan masa depan demokrasi di negeri ini karena ada lebih dari $80 \%$ umat Islam yang berfikiran moderat, inklusif, kritis dan responsif terhadap problem sosial-agama (Hasan: 2011).

Dalam hal ini, masih dalam riset CRSC, yang patut dikhawatirkan adalah tantangan yang bersumber dari sebanyak 19,9\% Muslim Indonesia yang bercirikan "islamis-ideologis" (Hasan: 2010). Tantangan itu berupa cara-cara pemaksaan politik identitas Islam di ruang publik yang berorientasikan pada klaim kebenaran sepihak, bahkan berupaya membisukan individu atau kelompok lain. Faktanya, setelah beberapa tahun hasil penelitian tersebut dipublikasikan kekhawatiran itu menjadi kenyataan sekarang. Politik kekerasan yang mengatasnamakan Islam melalui persekusi sedang merajalela dilakukan oleh kelompok islamis-ideologis. Front Pembela Islam (FPI) menjadi organisasi kemasyarakatan Islam yang banyak disorot publik dalam melakukan tindak persekusi terhadap pihak yang dianggap memiliki pandangan berbeda dari kelompoknya. Kathleen Azali (2017) dalam laporan risetnya menyebut FPI telah melakukan aksi persekusi sebanyak 59 kasus yang terlaporkan sepanjang Januari hingga Juni 2017.

Maraknya politik identitas Islam yang disimbolkan dengan aksi persekusi akhir-akhir ini mengaburkan nilai dan fungsi substantif ajaran agama. Watak keberagamaan harusnya ditampilkan dengan keramahan, toleransi dan moderat, bukan dengan wajah yang garang dan penuh ancaman meski orang lain memiliki pandangan yang berbeda. Pada tahap ini, jika fenomena persekusi ini terus berlangsung dengan ditunggangi faktor politik dan ekonomi, maka wujud pengakuan identitas Islam yang muncul di ruang publik akan selalu diwarnai ancaman yang berpotensi memudarkan wajah multikulturalisme bangsa kita.

\section{B. HASIL DAN PEMBAHASAN}

\section{Persekusi dan Watak Keberagamaan}

Kamus Besar Bahasa Indonesia menjelaskan, persekusi berarti "perburuan sewenangwenang terhadap seseorang atau sejumlah warga yang kemudian disakiti, dipersusah, atau ditumpas". Sementara merujuk pada Statuta Roma Pengadilan Kejahatan Internasional (1998), persekusi dianggap sebagai kejahatan kemanusiaan karena dapat menimbulkan perasaan menderita akibat pelecehan, penahanan dan ancaman. Statuta ini mendifinisikan persekusi sebagai perlakuan buruk atau penganiayaan secara sistematis oleh individu atau kelompok terhadap individu atau kelompok lain, khususnya karena suku, agama, etnis, budaya, gender dan pandangan politik. 
Maraknya aksi persekusi yang terjadi belakangan ini memiliki faktor pendorong yang bervariasi. Selain faktor agama, perburuan massa atau main hakim sendiri ini juga dilatarbelakangi atas kebencian berdasarkan sektarian. Fakta ini tidak bisa dibantah karena aksi persekusi muncul secara berbarengan sebagai dampak dari berjubelnya berita sampah (fake news) di media sosial dan Ahok effect, yaitu pencalonan Basuki Tjahaja Purnama (Ahok) di Pilkada DKI Jakarta (2017) yang memunculkan pertentangan dari kelompok islamis-ideologis. Ahok sendiri berasal dari etnis Tionghoa dan beragama Katolik. Merespons problem ini, Direktur Eksekutif Amnesty Internasional Perwakilan Indonesia Usman Hamid mengatakan, bahwa Pilkada DKI Jakarta 2017 adalah simbol kemunduran demokrasi. Pada Pilgub lalu itu, perbedaan antara kelompok yang mayoritas dan minoritas sangat ditonjolkan. Nilai kelompok harus diutamakan daripada nilai individu.

Paling tidak ada dua kejadian penting yang patut menjadi pusat perhatian bersama kaitannya dengan tindak persekusi beberapa waktu lalu. Dua kasus yang memilukan tersebut, yaitu: Pertama, persekusi atau perburuan oleh para anggota FPI atas Fiera Lovita (40 tahun), seorang dokter di RSUD Solok, Sumatera Barat. Wanita berjilbab ini mengalami ancaman dan intimidasi serius setelah menulis status di akun Facebook-nya yang berisi sindiran terhadap pemimpin FPI, Habib Rizieq atas kasus perbincangannya dengan Firza Husein karena berbau pornografi. Pada tulisan di statusnya itu, Fiera mempertanyakan alasan Habib Rizieq kenapa masih bersembunyi di Arab Saudi padahal dia mengklaim telah didukung 700 pengacara kenamaan dan jutaan umat Islam di Indonesia. Sontak tak butuh waktu lama, status itu menjadi viral, mendapatkan komentar miring yang menyebut dirinya telah menghina seorang ulama. Bahkan dia sendiri dikatakan sebagai perempuan pelacur dan komunis. Sehari kemudian, rumah sakit tempatnya bekerja dipenuhi dengan anggota FPI yang menuntut Fiera supaya meminta maaf. Ketika di rumah, juga dilempari puluhan orang tak dikenal dengan mengatakan komunis dan anti-Islam. Lebih kejam lagi dia disuruh meninggalkan Solok, sehingga demi keamanan maka dia dipindah ke Jakarta oleh Kementerian Koordinator Bidang Politik dan Keamanan (Kemenkopolhukam).

Kedua, kasus persekusi yang menjerat PMA (15 tahun), anak laki-laki keturunan Tionghoa yang berasal dari Jakarta Timur. Saat itu, Minggu (28/05/2017), tepat pukul 23.00, kos yang ditinggali PMA bersama ibu dan adik-adiknya didatangi sekitar 50 orang yang berasal dari FPI. Pintu kosnya digedor, dan PMA digelandang ke Balai RW di desa setempat, namun ibunya tidak ikut serta mendampingi karena harus menidurkan anak-anaknya yang lain. PMA disidang sekitar dua jam, di situlah dia mendapatkan kekerasan fisik. Dia ditampar, dipukuli, dan dipaksa menandatangi surat permohonan maaf karena menulis status yang bernada melecehkan FPI dan pimpinan mereka. Yang lebih memiluhkan lagi, setelah kejadian itu, dia dan keluarganya harus diusir dari kontrakan karena pemiliknya takut jika FPI melakukan ancaman kembali. Ibunya yang seorang janda juga dikeluarkan dari tempat kerja, karena kantor tempatnya bekerja lebih memilih jalan aman daripada didatangi FPI.

Sejujurnya, ada lebih banyak tindak persekusi yang dilakukan FPI kepada pihak-pihak yang memiliki pandangan berbeda, tetapi yang paling banyak disorot media dan menjadi perbincangan umum setidaknya ada dua kasus sebagaimana yang tersebut di atas (Azali: 2017). Berbagai kejadian persekusi akhir-akhir ini terjadi pada waktu yang saling berdekatan sehingga tampak kejadian semacam ini menjadi fenomena baru yang menyayat hati, namun sayang menggejala dalam nafas kehidupan berbangsa dan bernegara. Persekusi yang dialami Fiera Lovita dan PMA merupakan puncak dari ancaman dan kekerasan yang nyata dilakukan FPI. Pola perburuan massa dan main hakim sendiri ini, dapat kita katakan telah berjalan selama dua dekade terakhir. Hanya saja intensitasnya memuncak ketika bersamaan dengan pencalonan Ahok di Pilgub DKI Jakarta 2017, dan merasa mendapatkan dukungan pasca Demonstrasi berjilid-jilid yang didukung massa dalam jumlah besar, sehingga persekusi dapat disebut fenomena sosial baru yang mengusik kedamaian warga dalam beragama dan mengekspresikan pilihan politik mereka. 
Teror persekusi menyebar di dunia nyata dan media sosial. Anggota dan simpatisan FPI menebar kebencian dan melakukan ekstrimisme kekerasan melalui berbagai komentar di media sosial secara terorganisir. Menurut Kathleen, anggota dan simpatisan FPI semakin memiliki pemahaman yang luas dalam penggunaan media sosial. Mereka bisa mengidentifikasi secara sistematis akun siapa saja yang dianggap bernada melecehkan atau tidak setuju terhadap pergerakan anggota, organisasi dan pimpinan FPI. Cara sweaping di media sosial ini dilakukan untuk mengidentifikasi pihak-pihak yang tidak setuju terhadap pendapatnya, terutama untuk beberapa kasus yang menjadi konsen pergerakan mereka, seperti menghujat kelompok minoritas LGBTQ, Syiah, Ahmadiyah dan etnis Tionghoa.

Selama ini, FPI bergerak layaknya aparat keamanan yang menggunakan simbol keagamaan. Kelompok ini ingin melakukan "penertiban", yang sesuai dengan cara pandang mereka, tetapi kenyataannya justru membuat gaduh ketentraman publik dengan berupaya membisukan lainnya yang berbeda pandangan. Fiera Lovita, awalnya tidak menyangka bila status yang ditulisnya itu akan berefek luar biasa pada karir dan kehidupan keluarganya. Saat ini, menurut pegakuannya, anak perempuannya menjadi trauma jika melihat gerombolan massa, sementara dirinya tetap didera ketakutan karena pernah mendapatkan ancaman bertubi-tubi dari anggota FPI, bahkan beberapa pesan pendek yang masuk di gadgetnya berisi ancaman pembunuhan. PMA bersama ibu dan adik-adiknya mengalami trauma yang mendalam. Dia akhirnya mencari tempat tinggal yang lebih nyaman di Rumah Perlindungan Sosial Anak (RPSA) Jakarta Timur. Di RSPA ini, dia dan keluarganya mendapatkan konseling untuk pemulihan dari perasaan trauma. Kini, dia pindah dari Cipinang Muara Jakarta Timur ke lokasi baru yang dirahasiakan.

Sejumlah peristiwa persekusi yang terjadi belakangan ini sungguh ironis karena terjadi di negeri yang dikenal memberikan penghargaan besar terhadap multikulturalisme. Indonesia yang mempunyai lebih dari 17 ribu pulau, 34 provinsi dan 255 juta jiwa penduduknya membentuk lebih dari 300 etnis, 500 bahasa daerah, 6 agama resmi dan lebih dari 200 keyakinan lokal. Tanpa kekuatan Pancasila sebagai pondasi yang mengokohkan nilai-nilai multikultural, semua kemajemukan itu akan saling berbenturan. Pengalaman yang pernah terjadi pada 1999, dengan disulut isu primordialisme dan politik, konflik Islam-Kristen di Ambon dan Halmahera (Maluku) dan Poso (Sulawesi Tengah) meninggalkan luka yang menganga hingga sekarang (Wilson: 2008). Konflik komunal yang tidak kalah mengerikan juga terjadi antara suku Dayak dan orang Madura di Kalimantan Tengah (2001).

Argumentasi yang menyebut Indonesia sebagai teladan dalam aktualisasi multikultural diakui banyak sarjana, baik yang berasal dari dalam maupun luar negeri. Cultural Survival, sebuah lembaga non-profit berbasis di Amerika Serikat (AS) yang fokus pada isu-isu hak asasi manusia dan pembelaan atas masyarakat lokal, menyebut Indonesia sebagai sebuah negara yang telah memiliki konsep dan praktik multikulturalisme sejak lama. Ketika AS dan negara-negara lain di Eropa masih sibuk membicarakan urgensi multikulturalisme, bagaimana konsep dan aktualisasinya, warga Indonesia telah hidup damai dengan nafas "Bhinneka Tunggal Ika" (Cultural Survival Magazine, Juni 1994). Namun, ketika problem sosial bernama persekusi hadir menghantui warga, kekuatan multikulturalisme yang selama ini mendamaikan aneka keragaman dipertanyakan.

Sejumlah organisasi keagamaan yang datang belakangan, seperti halnya FPI menjadi aktor yang menggerogoti bangunan multikultural di Indonesia, yang sekaligus menginterupsi kenyamanan ormas-ormas Islam mainstream layaknya Muhammadiyah dan Nahdlatul Ulama. Kedua ormas Islam yang disebut terakhir itu dikatakan terlalu lembek dalam mencegah perilaku munkar (nahi munkar), sehingga dengan klaim sepihak itu mereka mengidentifikasi diri sebagai satu-satunya yang berani bergerak berbuat nahi munkar. Lebih dari itu, kemunculan FPI dengan atribut aksi memobilisasi massa yang mengatanamakan agama, dapat dikatakan sebagai strategi politik identitas di mana keberadaan mereka sebagai kelompok Islam ingin diakui di ruang publik. Apalagi, dalam berbagai khutbahnya, mereka beralasan bahwa mayoritas penduduk 
Indonesia adalah Muslim tetapi kepemimpinan nasional seringkali tidak berpihak kepada umat Islam. Dalam perspektif mereka, kebijakan ekonomi dan politik negeri ini seringkali menguntungkan kelompok pemodal, yang tidak lain berlatarbelakang agama non-Muslim dan beretnis Tiongkok.

Apa yang melatarbelakangi aksi intoleransi marak terjadi di negeri multukultur ini? Untuk mendapatkan jawabannya, sebuah pengamatan sederhana bisa dilakukan untuk melihat fenomena menggelisahkan ini melalui perbincangan di media sosial dan ceramah para da'i di sejumlah majelis. Melalui pengamatan yang sederhana itu, kita sering menjumpai komentar bernada kebencian dan permusuhan, seperti halnya perkataan "komunis", "kafir", "murtad" dan "liberal". Beberapa penyebutan streotip ini berjejalan di jejering media sosial yang ditujukan kepada pihak yang memiliki pandangan berbeda, terutama dalam hal pilihan politik dan perspektif keagamaan. Bermula dari streoptip-streotip di dunia maya, lalu berlanjut aksi persekusi di dunia nyata.

Kejadian yang dialami Fiera Lovita dan PMA merupakan puncak pengerasan pemahaman keagamaan pada sebagian masyarakat Muslim di Indonesia. Berdasarkan sedikit dalil keagamaan, sekelompok orang berlaku main hakim sendiri dan menggeser peran nalar kemanusiaan. Pada kondisi yang demikian ini, keadaban yang dimiliki orang Indonesia sebagai bagian dari bangsa Timur -khususnya umat Islam dalam hal ini-mengalami peluruhan signifikan. Pun demikian, semangat moderatisme yang sebelumnya melekat saat ini menemui kekaburan.

Potret Islam Indonesia yang dahulu penuh dengan keramahan, toleran dan moderat itu menjadi kabur seiring dengan perilaku sebagian Muslim yang suka mengolok-olok apabila terjadi perbedaan pandangan, serta mendahulukan ancaman dibanding dialog. Fenomena tersebut menjadi indikasi kuat yang menggerus watak moderatisme Islam di negeri ini (Bruinessen: 2011). Lunturnya watak kosmopolitanisme Islam itu paling tidak disebabkan oleh dua hal; Pertama, iklim politik yang serba terbuka seperti sekarang yang memberikan tempat bagi kelompok Islam skripturalis/literalis untuk bangkit dan mendesiminasikan pemikirannya yang khas: kaku, tertutup dan literatif.

Penilaian tersebut sama halnya dengan yang pernah diungkapkan William R. Liddle dalam melihat prospek keberagamaan umat Islam di Indonesia sejak jauh-jauh hari. Dia menjelaskan, "dalam iklim politik yang lebih terbuka, ekspresi Islam yang lebih skripturalis akan muncul ke permukaan" (Liddle: 1996). Kedua, periode modern yang ditandai dengan kemajuan sektor industri, oleh banyak sarjana Barat, secara otomatis akan meminggirkan umat Muslim. Tetapi kenyataan yang terjadi malah sebaliknya. Negara-negara Islam (termasuk yang mayoritas penduduknya Muslim) bukan mengalami kemunduran dengan kemajuan yang dialami Barat, melainkan memunculkan kelompok Islam dengan varian yang baru. Kelompok dengan varian yang baru tersebut adalah umat Islam yang menghadirkan simbol-simbol agama ke ruang publik.

\section{Rethinking Pendidikan Multikultural}

Secara etimologis, multikulturalisme berasal dari kata "multikultural" dan "isme". Kata "multikultural" memiliki arti "multi=banyak" dan "culture=budaya". Sementara "isme" adalah faham, ideologi, atau konsep. Pengertian literal ini cukup memberikan pemahaman awal bahwa multikulturalisme berarti paham, konsep dan ideologi politik mengenai bermacam budaya. Hanya saja, definisi multikulturalisme mengalami generalisasi yang beragam karena banyak antropolog yang mendifinisikan budaya secara bervariasi yang rasional dan argumentatif, misalnya saja Koentjaraningrat dan Edward Burnett Tylor. Koentjaraningrat (1979) mengatakan, "budaya adalah keseluruhan pengetahuan manusia sebagai makhluk sosial yang digunakan untuk memahami lingkungan, pengalaman dan pedoman perilaku mereka. Budaya terdiri dari unsurunsur universal, yaitu bahasa, teknologi, sistem ekonomi, organisasi sosial, pengetahuan, agama, dan seni. Sementara E.B. Tylor (2013) membatasi pengertian budaya sebagai "keseluruhan yang 
kompleks termasuk pengetahuan, kepercayaan, seni, moral, hukum, kebiasaan dan kemampuan lain yang dipelajari manusia sebagai anggota masyarakat".

Atas pengertian budaya yang beragam dan kompleks itu, maka diskusi multikulturalisme juga terus mengalami perluasan makna. Namun pada konteks aktualisasinya dalam sebuah negara, bangsa yang multikultural senantiasa memiliki satu ikatan kuat yang merajut segala perbedaan pada setiap warganya. Rajutan itu tidak didasarkan pada etnis, agama, golongan atau ras tertentu, tetapi pada komitmen politis yang menghubungkan segala kepentingan dari setiap entitas yang berbeda. Bikhu Parekh menyebutkan, bila komitmen politis yang mengakomodasi segala kepentingan plural itu dibuat, masyarakat multikultural akan bisa berdiri kokoh, stabil dan bertahan lama di tengah harmoni berbagai keragaman yang hidup dalam sebuah bangsa.

Meski sensitifitas primordial kerap menyulut terjadinya aksi kekerasan, namun konflik dapat teratasi secara bersama berkat komitmen politik yang terbentuk. Komitemen tersebut harus memenuhi kesejahteraan dan kepentingan setiap komunitas di dalamnya, sehingga integritas mereka senantiasa terpupuk (Parekh: 2000). Dalam komitmen tersebut, penting juga untuk melibatkan seluruh entitas yang ada, baik kelompok mayoritas maupun minoritas. Will Kymlica (2002) menjelaskan, komitmen multikultural perlu memberikan tempat bagi kelompok minoritas karena mereka juga memiliki hak kewargaan yang sama dalam negara-bangsa. Menurutnya, salah satu kegagalan demokrasi modern yang diterapkan oleh banyak negara Barat adalah pengabaian atas hak-hak kelompok minoritas.

Multikulturalisme merupakan satu bentuk politik pengakuan atas keberadaan entitas yang beragam dalam sebuah bangsa. Karena unsur penting di dalamnya adalah politik pengakuan atas kemajemukan, maka toleransi adalah sikap yang paling pokok. Kegagalan praktik multikultural yang digambarkan sejumlah negara di Eropa pada tiga dekade ke belakang sesungguhnya dilatarbelakangi atas ketidaksungguhan negara dalam menerima budaya baru yang dibawa oleh masyarakat migran. Pada satu sisi, warga migran yang umumnya berkulit hitam dan beragama Islam diterima masuk negara Yunani, Italia dan Spanyol, tetapi pada sisi yang lain warga lokal mengalami islamophopia yang berlebihan sebagai akibat dari merebaknya fundamentalisme keagamaan secara global. Atas fakta yang demikian ini, pemahaman tentang multikulturalisme di Barat belum selesai hingga sekarang. Bikhu Parekh menyindir atas kenyataan tersebut dengan mengatakan bahwa negara-negara di Eropa dapat menerima perbedaan, tetapi tidak semuanya mau mempraktikan multikulturalisme (Parekh: 2008).

Ketika negara-negara Barat sedang mendapatkan koreksi atas pemahaman dan praktik multikulturalisme (inilah yang membuat Bikhu Parekh menyebut perlunya melakukan rethinking multiculturalism), Indonesia justru telah memiliki modal sosial dan politik yang kokoh atas penghargaan pengakuan keberagaman ini sejak lama. Sayangnya, pasca Orde Baru, yang ditandai dengan kejatuhan Soeharto dan terjadinya kerusuhan antar etnis dan kelompok agama di berbagai daerah, membuat bangsa ini berpikir untuk mengokohkan kembali -jika tidak ingin dikatakan menghidupkan kembali- komitmen politis yang dicanangkan para pendiri bangsa.

Pancasila sebagai sebuah komitmen politik atas multikulturalisme telah dipraktikan dalam kehidupan kewargaan bangsa Indonesia sejak lama. Azyumardi Azra (2013) mengungkapkan, praktik multikulturalisme di Indonesia berusia sangat tua dibanding kemerdekaan Indonesia. Kata "multikulturalisme" memang relatif baru di telinga warga kita, tetapi aktualisasinya sudah lama bersemi, jauh sebelum bangsa-bangsa Eropa mendiskusikan mengenai pandangan dunia ini sekarang.

Persoalannya, praktik multikulturalisme saat ini sedang digerogoti kekuatan politik identitas yang memaksakan kehendak untuk tampil ke publik secara dominan. Kekuatan itu tidak berasal dari sentimen etnis dan ras, tetapi lebih besar lagi melibatkan kelompok agama, seperti halnya FPI. Akhir-akhir ini, FPI bertindak memonopoli narasi kebencian dan berlaku menyerupai aparat yang senantiasa memburu pihak yang memiliki pandangan berbeda. Kebencian dipupuk menjadi sumbu utama meledaknya aksi persekusi sebagaimana yang belakangan ini sering terjadi. Seseorang yang memiliki perspektif berbeda, misalnya dalam 
menilai kepemimpinan non-Muslim atau perilaku seorang yang dikatakan ulama oleh kelompok tertentu, "dipaksa" untuk diam, tidak diberikan ruang berpendapat walau sekedar menuliskannya di dinding Facebook atau Twitter pribadi. Kejadian yang seperti ini menemukan relevansinya dengan simpulan yang dipaparkan Muhamad Ali dalam sebuah kata pengantar di bukunya bertajuk Teologi Pluralis-Multikultural: Menghargai Kemajemukan Menjalin Kebersamaan (2003). Menurutnya, dewasa ini potret kemajemukan agama (pluralisme) dan kemajemukan budaya (multikulturalisme) Indonesia menghadapi tantangan serius, baik dari sisi pemikiran maupun pergerakan, dengan kemunculan organisasi keagamaan yang mengedepankan ekslusifisme dan fanatisme.

Fanatisme keagamaan yang diekspresikan dalam penguasaan ruang publik (baca: perusakan tempat hiburan, pemukulan aktivis HAM, aksi demonstrasi yang sarat kepentingan politik praktis, serta tindak persekusi terhadap pihak yang berbeda pendapat), belakangan ini dikonstruksi dengan varian sistem ide melalui berbagai pelabelan, seperti kafir, komunis, antiIslam, liberal, sesat, dan masuk neraka. Politik identitas "para pembela Tuhan" yang kerap disertai dengan pelabelan tidak lain merupakan upaya membisukan yang lain. Bentuk pendiaman semacam ini sama halnya dengan tidak mengakui keberadaan yang lain. Seolah-olah hanya mereka yang berhak menguasai ruang publik, dan bebas menyuarakan kemauannya, sementara yang lain diperintah untuk membisu. Menurut hemat penulis, kenyataan seperti ini ingin meniadakan jalan dialog, mengabaikan toleransi dan menyempitkan ruang yang mempertemukan di antara keberagaman. Padahal konsep ideal multikulturalisme adalah mengakomodasi segala perbedaan budaya, karena tindak persekusi merajalela sekarang ini, maka, "esensi dari citizenship yang merupakan co-existence", menjadi tidak berlaku di bumi pertiwi (priyatmono: 2007).

Telah menjadi pengetahuan umum bahwa Indonesia merupakan negara berpenduduk mayoritas muslim. Dari 237 juta jiwa total penduduknya (BPS: 2010), mereka yang memeluk Islam mencapai 87\%, sementara Katolik sebanyak 2,9\%, Kristen Protestan (6,9\%), Buddha $(0,05 \%)$, Hindu $(1,69 \%)$ dan Konghucu $(0,13 \%)$. Dari gambaran ini, menjadi jelas bahwa penduduk Indonesia adalah masyarakat yang beragama. Keberagaman agama yang yang menjadi ciri bagi bangsa ini, mestinya menjadi modal penting bagi terciptanya berbagai kemajuan. Terlebih dalam setiap agama mengajarkan nilai-nilai kesalehan. Dalam Islam, teks yang menyebutkan supaya umat muslim berlaku adil (al-Maidah: 8-10), peduli terhadap sesama (alMaun: 1-7), larangan saling bermusuhan (al-Hujurat: 12), serta merajut kebersamaan (al-Hujurat: 10), sangat ditekankan.

Watak keberagamaan, yang berarti penuh dengan nilai inklusif, merupakan modal penting bagi kekokohan multikulturalisme. Namun, mengapa masyarakat sekarang digandrungi dengan narasi kebencian yang direproduksi menjadi tindakan persekusi. Orang mencuri sandal dipukuli dan dibakar hingga meninggal dunia; seorang pemuda menulis status di Facebook lalu dipersekusi oleh kelompok yang mengatasnamakan agama; serta wanita baik-baik, dokter, berjilbab, pintar, up date status menanggapi kasus yang menjerat pemimpin Ormas Islam tertentu diancam melalui pesan pendek dan komentar di media sosial secara bertubi-tubi hingga mau dibunuh!

Sebab itu, untuk menyelamatkan generasi masa depan, maka penting mendesakkan kurikulum pendidikan yang berbasiskan multikulturalisme. Selama ini, memang telah ada muatan materi yang mengenalkan tentang keberagaman melalui Pendidikan Pancasila dan Kewarganegaraan (PPKN), namun implementasinya masih sebatas wacana yang tetap memunculkan sikap toleransi yang masih pasif. Berbeda dengan konsep pendidikan multikultural, di mana peserta didik dikenalkan tentang urgensi perbedaan lebih dari sekedar menghafal dan mempelajarinya melalui buku ajar, tapi praktik dan keteladanan dari seluruh stakeholder di sekolah sangat penting untuk mereka adopsi.

Gejala intoleransi dan radikalisasi keagamaan yang semakin mengkristal, baik di lingkungan peserta didik maupun mahasiswa (Muthohirin: 2014), juga berkontribusi besar 
terhadap pemahaman keagamaan masyarakat Muslim yang semakin konservatif. Penyebab ini salah satunya karena pihak sekolah masih dinilai kurang dalam implementasi pendidikan yang berbasiskan multikulturalisme.

Salah satu teladan yang cukup baik dalam merealisasikan model pendidikan multikultural adalah seperti yang dicontohkan Muhammadiyah. Beberapa tahun terakhir, organisasi Islam terbesar di Indonesia dalam aspek pendidikannya ini tengah mengembangkan sebuah kurikulum pembelajaran mata kuliah khas bernama Al-Islam dan Kemuhammadiyahan (AIK) Multikultural. Di antara beberapa materinya memuat tentang inklusivisme, penghargaan terhadap kelompok agama berbeda, dan konsep wasathiyyah Islam. AIK Multikultural ini akan diimplementasikan di 6 Perguruan Tinggi Muhammadiyah (PTM) di daerah-daerah yang penduduknya mayoritas non Muslim, di antaranya Universitas Muhammadiyah Sorong, Universitas Muhammadiyah Kupang, IKIP Muhammadiyah Maumere, STIKOM Jayapura, STKIP Muhammadiyah Manokwari, dan STKIP Muhammadiyah Sorong. Ketua Majelis Diktilitbang PP Muhammadiyah Lincolin Arsyad menjelaskan, di kampus-kampus tersebut jumlah mahasiswa non-muslimnya mencapai sekitar 60\% - 80\% (Arifin \& Muthohirin: 2019).

\section{KESIMPULAN}

Aksi persekusi yang melibatkan kelompok agama akhir-akhir ini sarat dengan kepentingan politik identitas. FPI, yang dalam hal ini banyak dibincangkan, mengklaim diri sebagai sebuah organisasi kemasyarakatan Islam yang ingin diakui paling berani menyuarakan kepentingan umat Islam. Akibat klaim sepihak itu, ujaran kebencian dan penggunaan kekerasan dianggap benar. Alih-alih ingin mencegah perbuatan yang munkar, tapi justru penghakiman yang dilakukan menjadi upaya untuk membisukan liyan. Parahnya, kondisi yang demikian ini dipertebal dengan kesadaran beragama masyarakat yang dipolitisasi untuk kepentingan politik praktis. Sangat wajar jika kita sering menjumpai mobilisasi massa umat Islam dalam aksi demonstrasi, spanduk bernada ancaman terhadap pemimpin non-Muslim, atau ceramah-ceramah keagamaan yang mengutuk demokrasi dan pemerintahan yang berlindung di bawahnya.

Fenomena ini menjelaskan bahwa pada satu sisi kesadaran beragama umat Islam Indonesia mengalami kebangkitan, hanya saja tidak diiringi dengan kesadaran kritis dalam memahami doktrin agama pada sisi yang lain. Ujaran kebencian, mudah emosional dan mempersekusi pihak yang berbeda pendapat menjadi "karya" nyata yang dihasilkan oleh kesadaran masyarakat dalam beragama yang tidak substantif seperti ini. Harusnya, kebangkitan publik dalam mengimani keyakinannya dapat diimplementasikan untuk kemanfaatan bersama, membangun kemajuan bangsa dan agama. Dengan demikian, potret multikulturalisme yang menjadi ciri bangsa ini akan senantiasa terjaga.

Pada tahap ini, upaya memikirkan kembali urgensi multikulturalisme sangat diperlukan. Untuk meneguhkan pondasi multikulturalisme itu, satu-satunya cara yaitu dengan mempraktikan berbagai modal sosial (toleransi, sopan-santun, dialog, ramah-tamah, dan lainnya) yang telah diwariskan nenek moyang bangsa ini. Melalui kesederhanaan sikap seperti inilah wujud berbangsa yang tidak cinta terhadap aksi-aksi kekerasan ini terbentuk. Namun, modal atau semangat sosial yang tinggi dari bangsa ini tidaklah cukup untuk menuju kesempurnaan berbangsa nirkekerasan jika negara mengalami kelumpuhan menjalankan sistem pemerintahan yang bijak. Dalam hal ini, hendaknya pemerintah perlu melakukan beberapa tindakan progresif, yang diantaranya dengan memberikan tempat bagi perlindungan hukum dan HAM, menegakkan demokrasi, dan mengakomodasi segala keberagaman mulai etnis, suku, budaya, dan agama. Kini, berbangsa nirkekerasan adalah "lompatan kuantum" yang merefleksikan terbentuknya peradaban tinggi dalam lanskap berbangsa, bernegara dan beragama. 


\section{DAFTAR PUSTAKA}

Ali, Muhamad. 2003. Teologi Pluralis-Multikultural: Menghargai Kemajemukan Menjalin Kebersamaan. Jakarta, Kompas.

Arifin, Syamsul dan Nafik Muthohirin. 2019. "The View Point of the Young Intellectual Muhammadiyah Towards the Religious Minority Groups in Indonesia", Teosofi Jurnal Tasawuf dan Pemikiran Islam. Volume 9, Nomor 2. (Desember).

Azali, Kathleen. 2017. "Fake News and Increased Persecution in Indonesia", PERSPECTIVE. Number, 16. Singapore, ISEAS-Yusof Ishak Institute (Agustus).

Bruinessen, Martin Van. 2011. "What Happened to the Smiling Face of Indonesian Islam? Muslim Intellectualism and the Conservative Turn in Post-Suharto Indonesia", RSIS Working Paper, No. 222. (6 Januari)

Hasan, Noorhaidi. 2010. "Ideologi, Identitas dan Ekonomi Politik Kekerasan", Prisma, Vol. 29. Jakarta, LP3ES (Oktober)

Hasan, Noorhaidi dan Abu Bakar, Irfan (ed.). 2011. Islam di Ruang Publik: Politik Identitas dan Masa Depan Demokrasi di Indonesia. Jakarta, CRSC.

Hasan, Noorhaidi. 2008. Laskar Jihad: Islam, Militansi dan Pencarian Identitas Indonesia Pasca Orde Baru. Jakarta, LP3ES.

Karami, Jahangir. "External Politics from the View of Social Constitutionalism" Journal of Strategy, No. 31. Spring

Kymlica, Will. 2002. "Kewargaan Multikultural: Teori Liberal Mengenai Hak-hak Minoritas". Jakarta, LP3ES.

Latif, Yudi. 2017. Negara Paripurna: Historisitas, Rasionalitas dan Aktulitas Pancasila. Cet ke6. Jakarta, Gramedia.

Liddle, William R. 1996. "The Islamic Turn in Indonesia: A Political Explanation”, The Journal of Asian Studies. Vol. 55, No. 3 (Agustus)

Lorraine V, Aragon. 1994. "Multiculturalism: More Lessons From Indonesia”. Cultural Survival Magazine (Juni)

Muthohirin, Nafi'. 2014. Fundamentalisme Islam: Gerakan dan Tipologi Aktivis Islam Kampus. Jakarta, IndoStrategi.

.2015. "Radikalisme Islam dan Pergerakannya di Media Sosial", Jurnal AFKARUNA-Universitas Muhammadiyah Yogyakarta, 240-259.

Parekh, Bikhu. 2000. Rethinking Multiculturalism: Cultural Diversity and Political Theory. London, SAGE Publication.

Ricklefs, M.C. 2013. Mengislamkan Jawa: Sejarah Islamisasi di Jawa dan Penentangnya dari 1930 sampai Sekarang. Jakarta, Serambi.

Syafii Maarif, Ahmad. 2009. Islam dalam Bingkai Keindonesiaan dan Kemanusiaan: Sebuah Refleksi Sejarah. Jakarta, Mizan.

Wasino. 2013. "Indonesia: From Pluralism to Multiculturalism”, Paramita, Vol. 23. No. 2 (Juli)

Wilson, Chris. 2008. Ethno-Religious Violence in Indonesia: From Soil to God. New York, Routledge. 